\title{
SYNTHESES AND CHARACTERIZATIONS OF COPPER COMPLEXES: INTERACTION OF COPPER ACETATE DIHYDRATE WITH 4,4'-BIPYRIDINE
}

\author{
GLORIA V. SEGUEL*, BERNABÉ L. RIVAS, PEDRO ÓRDENES \\ Facultad de Ciencias Químicas, Universidad de Concepción, Casilla 160-C, Concepción, Chile
}

\begin{abstract}
Two complexes have been synthesized through the reaction of copper(II) acetate dihydrate with 4,4'-bipyridine. Both were characterized by elemental analysis, magnetic moment, FT-IR spectroscopy, and thermogravimetric analysis. Semiempirical structural DFT studies of $\left[\mathrm{Cu}_{2}\left(\mathrm{CH}_{3} \mathrm{COO}\right)_{4}(4,4 . b i p y)_{2}\right]_{\mathrm{n}}$ and $4,4^{\prime}$ bipyridine were carried out.

4,4'-Bipyridine acts as bidentate ligand, breaking the $\mathrm{Cu}_{2}\left(\mathrm{CH}_{3} \mathrm{COO}\right)_{4}$ unit and acting as bridge between the metal centers, yielding a polymeric structure bearing monodentate acetate groups. The compounds $\left[\mathrm{Cu}_{2}\left(\mathrm{CH}_{3} \mathrm{COO}\right)_{4}(4,4-\text { bipy })_{2}\right]_{\mathrm{n}}$ and $\left[\mathrm{Cu}_{2}\left(\mathrm{CH}_{3} \mathrm{COO}\right)_{4}(4,4-\text { bipy })_{2}\left(\mathrm{H}_{2} \mathrm{O}\right)_{2}\right]_{\mathrm{n}}$ have magnetic moments of 1.83 and 1.77 B.M, respectively. These values are higher than those of copper (II) acetate monohydrate (1.4 B.M).
\end{abstract}

Keywords: metallic acetates, 4,4'-bipyridine, DFT calculations.

\section{INTRODUCTION}

Metal complexes with carboxylates and nitrogen ligand are the subject of particular interest due to their biochemical importance. Several studies of copper(II) acetate complexes with nitrogen ligands, such as pyridine, aminopyrimidine, bipyridyl, and nicotinamide, have been reported. Instead of forcing dissociation of the dinuclearCu $\mathrm{Cu}_{2}\left(\mathrm{CH}_{3} \mathrm{COO}\right)_{4}$ units, these ligands simply replace bound water molecules, causing only small changes in the $\mathrm{Cu}-$ $\mathrm{Cu}$ distances (Figure 1) [1-4]. Similar behavior has been found with polymeric ligands containing nitrogen functional groups $[5,6]$.

The imidazole ligand has been reported to force dissociation of the $\mathrm{Cu}_{2}\left(\mathrm{CH}_{3} \mathrm{COO}\right)_{4}$ unit, resulting in a square planar copper(II) complex that exhibits anticancer properties [7].

Reactions with carboxylic acids, such as poly(DL-aspartic acid), cause the loss of an acetate group from $\mathrm{Cu}_{2}\left(\mathrm{CH}_{3} \mathrm{COO}\right)_{4}[8]$.

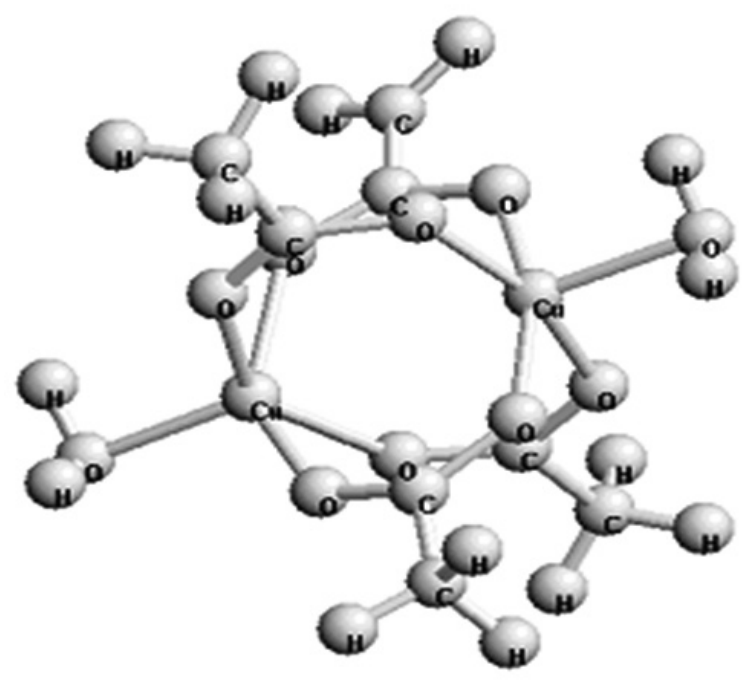

Figure 1. Computational model of the $\left[\mathrm{Cu}_{2}\left(\mathrm{OOCCH}_{3}\right)_{4}\left(\mathrm{H}_{2} \mathrm{O}\right)_{2}\right]$ complex.

In a recent study [9], we reported the reaction of copper(II) acetate monohydrate with 1,3-thiazol, yielding a compound wherein the 1,3-thiazol replaces the water molecules without inducing significant changes to the original magnetic moment of copper(II) acetate dihydrate (1.4 B.M).

The interactions of copper(II) acetate monohydrate with 2,2-bipy ligands in a variety of solvents have been reported. In DMF, the formation of monomeric $\left[\mathrm{Cu}\left(\mathrm{O}_{2} \mathrm{CMe}\right)_{2}\right.$ (bipy) $]$ was observed. This complex has a square planar geometry about $\mathrm{Cu}$ with a chelating, bidentate bipy group and monodentate acetate ligands [10]. However, in $\mathrm{MeCN}$ or ethanol, a dimeric $\left[\mathrm{Cu}_{2}\left(\mathrm{O}_{2} \mathrm{CMe}\right)_{4}(\text { bipy })_{2}\right] \cdot 2$ $\mathrm{H}_{2} \mathrm{O}$ compound with two bridging acetates, two monodentate acetates and two bidentate 2,2-bipy ligands was obtained [11,12].

The 4,4'-bipyridine ligand is very interesting due to its capacity to behave as a bifunctional ligand. This bifunctionality allows the ligand to coordinate to two metal centers, enabling the formation of polymeric coordination compounds.

The preparation of $\mathrm{Cu}(\mathrm{II})$ complexes with salicylate and 4,4'-bipyridine ligands was carried out in different solvents, giving polymeric complexes of the general formula $\left[\mathrm{Cu}(\mathrm{Hsal})_{2}(4,4-\text { bipy })_{\mathrm{n}}\right]$, with different structures [13].

The aim of this manuscript is to describe the interaction of 4,4'-bipy with copper(II) acetate monohydrate.

\section{EXPERIMENTAL}

\section{Materials}

The metal salt $\mathrm{Cu}_{2}\left(\mathrm{CH}_{3} \mathrm{COO}\right)_{4} \cdot 2 \mathrm{H}_{2} \mathrm{O}$ was analytical grade (Aldrich). The ligand $4,4^{\prime}$-bipyridine was purchased from Merck.

Synthesis of $\left[\mathrm{Cu}_{2}\left(\mathrm{CH}_{3} \mathrm{COO}\right)_{4}\left(4,4^{\prime} \text {-bipy }\right)_{2}\right]_{n}$

Copper(II) acetate $(0.5 \mathrm{~g})$ was suspended in $30 \mathrm{~mL}$ of ethanol. In parallel, $0.8 \mathrm{~g}$ of 4,4'-bipy was dissolved in a small amount of ethanol. The solutions were mixed and stirred overnight. A light blue precipitate formed, which was filtered and washed with ethanol.

Synthesis of $\left[\mathrm{Cu}_{2}\left(\mathrm{CH}_{3} \mathrm{COO}\right)_{4}\left(4,4^{\prime}-\text { bipy }\right)_{2}\left(\mathrm{H}_{2} \mathrm{O}\right)_{2}\right]_{n}$

Copper(II) acetate $(0.5 \mathrm{~g})$ was dissolved in $30 \mathrm{~mL}$ of water. In parallel, 0.8 $\mathrm{g}$ of $4,4^{\prime}$-bipy was dissolved in approximately $5 \mathrm{~mL}$ of ethanol. The solutions were mixed and stirred for $24 \mathrm{~h}$. A lila-colored precipitate formed, which was filtered and washed with a water-ethanol mixture.

Both compounds were dried at room temperature. Both were insoluble in water and organic solvents. The $\left[\mathrm{Cu}_{2}\left(\mathrm{CH}_{3} \mathrm{COO}\right)_{4}\left(4,4^{\prime} \text {-bipy }\right)_{2}\left(\mathrm{H}_{2} \mathrm{O}\right)_{2}\right]_{\mathrm{n}}$ complex behaves as thermochromic material. Heating to $47^{\circ} \mathrm{C}$ induces the loss of the water molecules, with a concomitant change in color to a light sky blue. If the compound is re-suspended in water, it regains its lilac color.

$\left[\mathrm{Cu}_{2}\left(\mathrm{CH}_{3} \mathrm{COO}\right)_{4}\left(4,4^{\prime} \text {-bipy }\right)_{2}\left(\mathrm{H}_{2} \mathrm{O}\right)_{2}\right]_{\mathrm{n}} \stackrel{47^{\circ} \mathrm{C}}{\longleftrightarrow} \quad\left[\mathrm{Cu}_{2}\left(\mathrm{CH}_{3} \mathrm{COO}\right)_{4}(4,4\right.$. bipy $\left.)_{2}\right]_{\mathrm{n}}+2 \mathrm{H}_{2} \mathrm{O}$

$\left[\mathrm{Cu}_{2}\left(\mathrm{CH}_{3} \mathrm{COO}\right)_{4}(4,4 . \text { bipy })_{2}\right]_{0}$

Elemental analysis: (Found: $\mathrm{Cu}: 18.5 \%$, N: $8.1 \%$, C: 49.2\%, H:5.2 \%.

Calcd.: Cu: $18.8 \%$, N: $8.3 \%$, C: $49.7 \%$, H: $4.1 \%$ ).

$\left[\mathrm{Cu}_{2}\left(\mathrm{CH}_{3} \mathrm{COO}\right)_{4}\left(4,4^{\prime}-\text { bipy }\right)_{2}\left(\mathrm{H}_{2} \mathrm{O}\right)_{2}\right]$

Elemental analysis: (Found: Cu: $17.8 \%$, N: $7.3 \%$, C: 43.4\%, H: $5.2 \%$.

Calcd.: Cu: $17.9 \%$, N: $7.9 \%$, C: $47.2 \%$, H: $4.5 \%$ )

Measurements

Copper(II) was analyzed by atomic absorption spectrometry with a Perkin Elmer model $5300 \mathrm{DV}$. Elemental analyses $(\mathrm{C}, \mathrm{H}$ and $\mathrm{N})$ were obtained on an EA 1108 Analyzer Elemental, Fision Instruments.

FT-IR spectra were recorded on a Nicolet Magna 550 and a Nicolet Nexus spectrophotometer. Magnetic susceptibility measurements were performed at room temperature on a Sherwood Auto Magnetic Susceptibility Balance by the Gouy method using $\mathrm{Hg}\left[\mathrm{Co}(\mathrm{SCN})_{4}\right]$ as the calibration standard. From the observed susceptibility, the magnetic moment $\left(\mu_{\text {eff }}\right)$ was calculated using the 
following formula: $\mu_{\text {eff }}=2.824 \sqrt{X_{M} T}$. The diamagnetic contribution due to the core electrons was estimated using Pascal constants and subtracted from the experimental values.

Thermogravimetric analysis was carried out on a Netzsch model TG 209 F1, Iris. High quality $\mathrm{N}_{2(\mathrm{~g})}$ was used at a flux of $250 \mathrm{~mL} / \mathrm{min}$.

Quantum Chemical Calculations

Quantum DFT calculations were performed using the GAUSSIAN98 package. Becke's three-parameter hybrid functional B3LYPand LANL2DZ basis augmented with d-polarization functions on heavy atoms were applied for the complexes. The ligands were studied at the B3LYP/6-31G $(\mathrm{d}, \mathrm{p})$ level. The compounds were createdusing the HyperChem software.

\section{RESULTS AND DISCUSSION}

According to the elemental analyses of the synthesized compounds, $\mathrm{Cu}_{2}\left(\mathrm{CH}_{3} \mathrm{COO}\right)_{4}(4,4 \text {-bipy })_{2}$ and $\mathrm{Cu}_{2}\left(\mathrm{CH}_{3} \mathrm{COO}\right)_{4}(4,4-\text { bipy })_{2}\left(\mathrm{H}_{2} \mathrm{O}\right)_{2}$ were deemed appropriate formulae for the isolated materials.

For $\left[\mathrm{Cu}_{2}\left(\mathrm{CH}_{3} \mathrm{COO}\right)_{4}(4,4-\text { bipy })_{2}\right]_{\mathrm{n}}$, we suggest a structure wherein the $4,4^{\prime}$ bipy ligand bridges the dimeric $\mathrm{Cu}_{2}\left(\mathrm{CH}_{3} \mathrm{COO}\right)_{4}$. The formation of the resultant polymeric structure is facilitated by the capacity of the bipy ligand to act as a bifunctional bridge between two metallic centers, leaving the acetate groups coordinated to the metal in a monodentate fashion (see Figure 2).

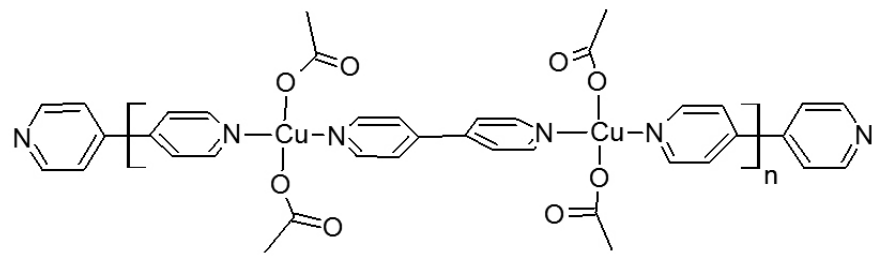

Figure 2. $\left[\mathrm{Cu}_{2}\left(\mathrm{CH}_{3} \mathrm{COO}\right)_{4}\left(4,4^{\prime}-\text { bipy }\right)_{2}\right]_{\mathrm{n}}$

A similar structure is likely for $\left[\mathrm{Cu}_{2}\left(\mathrm{CH}_{3} \mathrm{COO}\right)_{4}\left(4,4^{\prime} \text {-bipy }\right)_{2}\left(\mathrm{H}_{2} \mathrm{O}\right)_{2}\right]_{\mathrm{n}}$, with the exception that a water-molecule is coordinated to each copper atom, making the metal center pentacoordinate.

The IR spectra of both compounds are very similar. Both show the asymmetric and symmetric strength vibrations of acetate groups at $1605 \mathrm{~cm}^{-1}$ and $1388 \mathrm{~cm}^{-1}$ with a $\Delta v\left[v\left(\mathrm{COO}^{-}\right)_{\text {as }}-v\left(\mathrm{COO}^{-}\right)_{\mathrm{s}}\right]$ value of $217 \mathrm{~cm}^{-1}$. This $\Delta v$ is higher than the $\Delta v$ of sodium acetate, which has a value of $164 \mathrm{~cm}^{-1}$; therefore, monodentate coordination seems likely (see Table 1) [14].

Table 1. FT-IR absorption signals $\left(\mathrm{cm}^{-1}\right)$ of $4.4^{\prime}$-bipyridine(L), $\left[\mathrm{Cu}_{2}\left(\mathrm{CH}_{3} \mathrm{COO}\right)_{4} \cdot 2 \mathrm{H}_{2} \mathrm{O}\right]$, and the studied complexes.

\begin{tabular}{|c|c|c|c|c|}
\hline $\mathbf{v}\left(\mathbf{c m}^{-1}\right)$ & $\mathrm{Cu}_{2}\left(\mathrm{CH}_{3} \mathrm{COO}\right)_{4} \cdot 2 \mathrm{H}_{2} 0$ & {$\left[\mathrm{Cu}_{2}\left(\mathrm{CH}_{3} \mathrm{COO}\right)_{4}\left(\mathrm{~L}_{2}\right]_{\mathrm{n}}\right.$} & {$\left[\left[\mathrm{Cu}_{2}\left(\mathrm{CH}_{3} \mathrm{COO}\right)_{4}(\mathrm{~L})_{2}\left(\mathrm{H}_{2} 0\right)_{2}\right]_{\mathrm{n}}\right.$} & $\mathbf{L}$ \\
\hline $\begin{array}{c}v\left(\mathrm{COO}^{-}\right) \\
\text {as }\end{array}$ & 1608 & 1605 & 1605 & \\
\hline \begin{tabular}{c}
$v(\mathrm{COO}) \mathrm{s}$ \\
\hline$v(\mathrm{C}=\mathrm{N})$
\end{tabular} & 1440 & 1388 & 1388 & 1492 \\
\hline $\begin{array}{c}\text { Ring } \\
\text { breathing }\end{array}$ & 168 & 1018 & 1018 & 985 \\
\hline \multicolumn{2}{|c|}{} & 217 & 217 & \\
\hline
\end{tabular}

Magnetic measurements

$\left[\mathrm{Cu}_{2}\left(\mathrm{CH}_{3} \mathrm{COO}\right)_{4}(4,4-\text { bipy })_{2}\right]_{\mathrm{n}}$ and $\left[\mathrm{Cu}_{2}\left(\mathrm{CH}_{3} \mathrm{COO}\right)_{4}(4,4-\text { bipy })_{2}\left(\mathrm{H}_{2} \mathrm{O}\right)_{2}\right]_{\mathrm{n}}$ have magnetic moments of 1.83 and 1.77 B.M., respectively. These values are higher than those measured for copper(II) acetate monohydrate (1.4 M.B).In $\left[\mathrm{Cu}\left(\mathrm{CH}_{3} \mathrm{COO}\right)_{2} \cdot \mathrm{H}_{2} \mathrm{O}\right]$, the observed magnetic moment of $1.4 \mathrm{~B} . \mathrm{M}$. is related to the close proximity of the two copper(II) ions ( $2.64 \AA$ ). The precise mechanism of this interaction is not clear; it may involve a direct copper-copper bond or a super exchange mechanism via the bridging acetate ligands $[15,16]$.

Compounds wherein the core $\mathrm{Cu}_{2}\left(\mathrm{CH}_{3} \mathrm{COO}\right)_{4}$ unit is maintained tend to show abnormally low magnetic moments, such as $\left[\mathrm{Cu}_{2}\left(\mathrm{CH}_{3} \mathrm{COO}\right)_{4}(\mathrm{Tz})_{2}\right]$, with a magnetic moment of 1.4 B.M [9], and $\left[\mathrm{Cu}_{2}\left(\mathrm{CH}_{3} \mathrm{COO}\right)_{4}(1,3 \text {-benzothiazole })_{2}\right]$, with a reported value 1.42 B.M. [17].
Thermogravimetric analysis

According to the TGA measurements, $\left[\mathrm{Cu}_{2}\left(\mathrm{CH}_{3} \mathrm{COO}\right)_{4}\left(4,4^{\prime} \text {-bipy }\right)_{2}\right]$ shows the loss of two $4,4^{\prime}$-bipy molecules at $236.4^{\circ} \mathrm{C}$ and 4 acetate ions at $271.4^{\circ} \mathrm{C}$.

The sequence of the decomposition reactions, as deduced from TGA studies, is summarized below:

$\mathrm{Cu}_{2}\left(\mathrm{CH}_{3} \mathrm{COO}\right)_{4}\left(4,4^{\prime} \text {-bipy }\right)_{2} \rightarrow \mathrm{Cu}_{2}\left(\mathrm{CH}_{3} \mathrm{COO}\right)_{4}+2$ (4,4'-bipy)

$\mathrm{Cu}_{2}\left(\mathrm{CH}_{3} \mathrm{COO}\right)_{4} \rightarrow 2 \mathrm{CuO}_{4}+4 \mathrm{CH}_{3} \mathrm{COO}^{-}$

$\left[\mathrm{Cu}_{2}\left(\mathrm{CH}_{3} \mathrm{COO}\right)_{4}\left(4,4^{\prime} \text {-bipy }\right)_{2}\left(\mathrm{H}_{2} \mathrm{O}\right)_{2}\right]_{n}$ loses two water molecules at $46.7^{\circ} \mathrm{C}$ two $4,4^{\prime}$-bipy molecules at $238.2^{\circ} \mathrm{C}$, and four acetate ions at $260^{\circ} \mathrm{C}$ (see Figure $3)$.

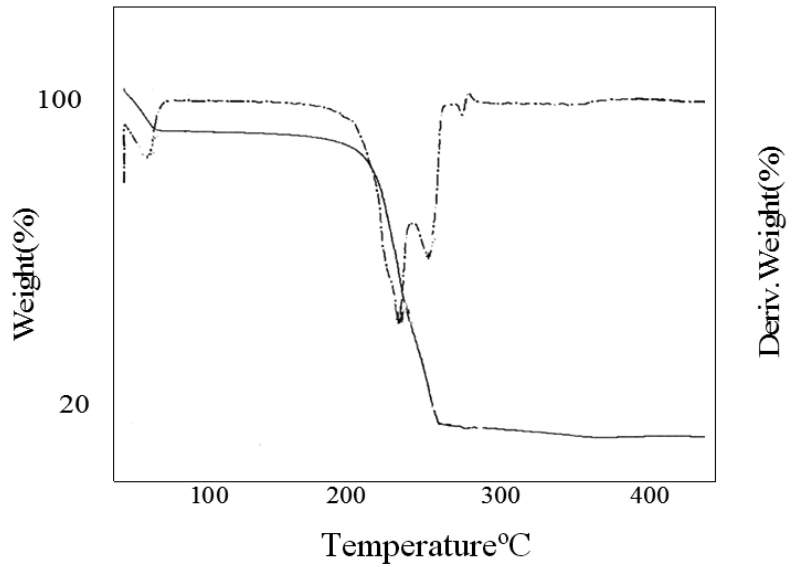

Figure 3. TGA and DTG curves of $\left[\mathrm{Cu}_{2}\left(\mathrm{CH}_{3} \mathrm{COO}\right)_{4}\left(4,4^{\prime} \text {-bipy }\right)_{2}\left(\mathrm{H}_{2} \mathrm{O}\right)_{2}\right]_{\mathrm{n}}$

The sequence of the decomposition reactions, as deduced from TGA studies, is summarized below: $2 \mathrm{H}_{2} \mathrm{O}$

$\mathrm{Cu}_{2}\left(\mathrm{CH}_{3} \mathrm{COO}\right)_{4}\left(4,4^{\prime} \text {-bipy }\right)_{2}\left(\mathrm{H}_{2} \mathrm{O}\right)_{2} \rightarrow \mathrm{Cu}_{2}\left(\mathrm{CH}_{3} \mathrm{COO}\right)_{4}\left(4,4^{\prime} \text {-bipy }\right)_{2}+$

$\mathrm{Cu}_{2}\left(\mathrm{CH}_{3} \mathrm{COO}\right)_{4}\left(4,4^{\prime} \text {-bipy }\right)_{2} \rightarrow \mathrm{Cu}\left(\mathrm{CH}_{3} \mathrm{COO}\right)_{2}+2\left(4,4^{\prime}-\right.$ bipy $)$

$\mathrm{Cu}_{2}\left(\mathrm{CH}_{3} \mathrm{COO}\right)_{4}$

$\rightarrow 2 \mathrm{CuO}+4 \mathrm{CH}_{3} \mathrm{COO}^{-}$

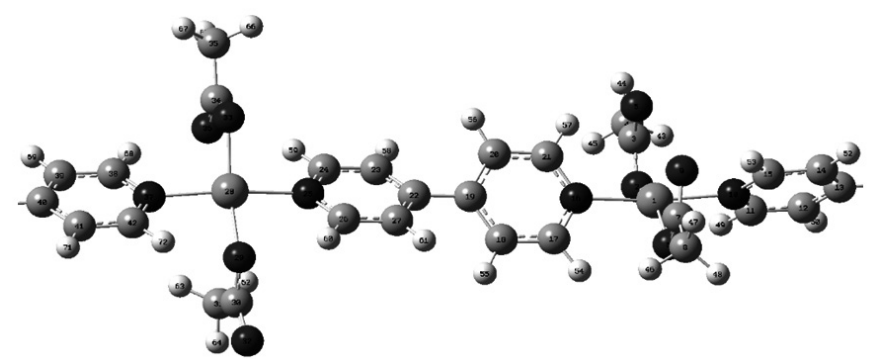

Figure 4. DFT calculated structure of $\left[\mathrm{Cu}_{2}\left(\mathrm{CH}_{3} \mathrm{COO}\right)_{4}\left(4,4^{\prime} \text {-bipy }\right)_{2}\right]_{\mathrm{n}}$

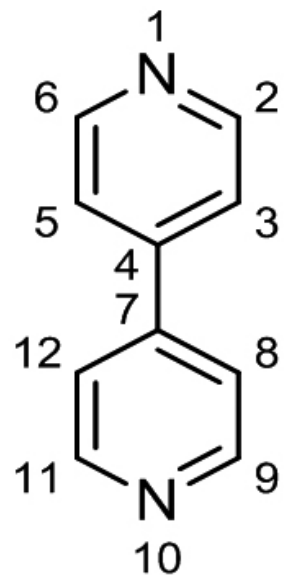

Figure 5. Numbering scheme for the 4,4'-bipyridine ligand. 
Table 3. Selected DFT-optimized structural parameters of $\left[\mathrm{Cu}_{2}\left(\mathrm{CH}_{3} \mathrm{COO}\right)_{4}(4,4 \text {.bipy })_{2}\right]_{\mathrm{n}}$ and $4,4^{\prime}$ - bipyridine.

\begin{tabular}{|c|c|c|}
\hline & $\underset{\left.\text { bipy })_{2}\right]_{\mathrm{n}}}{\left[\mathrm{Cu}_{2}\left(\mathrm{CH}_{4} \mathrm{COO}\right)_{4}\right.}(4,4$. & 4,4'-bipyridine \\
\hline \multicolumn{3}{|l|}{ Length of bond $\left(A^{\circ}\right)$} \\
\hline \multirow{4}{*}{$\mathrm{Cu}-\mathrm{N}$} & 2,0874 & \\
\hline & 2,09675 & \\
\hline & 2,08151 & \\
\hline & 2,07323 & \\
\hline \multirow[t]{4}{*}{$\mathrm{Cu}-\mathrm{O}$} & 1,97065 & \\
\hline & 1,97028 & \\
\hline & 1,96028 & \\
\hline & 1,92370 & \\
\hline \multicolumn{3}{|l|}{ Bond angle $\left({ }^{\circ}\right)$} \\
\hline \multirow[t]{2}{*}{$\mathrm{N}-\mathrm{Cu}-\mathrm{N}$} & 173,09690 & \\
\hline & 169,74261 & \\
\hline \multirow[t]{2}{*}{$\mathrm{O}-\mathrm{Cu}-\mathrm{O}$} & 156,25230 & \\
\hline & 152,82095 & \\
\hline \multirow[t]{2}{*}{$\mathrm{C}(5)-\mathrm{C}(4)-\mathrm{C}(7)-\mathrm{C}(12)$} & 36,88494 & $-36,31045$ \\
\hline & 36,43657 & $-36,31105$ \\
\hline \multirow[t]{2}{*}{$\mathrm{C}(5)-\mathrm{C}(4)-\mathrm{C}(7)-\mathrm{C}(8)$} & $-143,23883$ & 143,68910 \\
\hline & $-143,43966$ & 143,68941 \\
\hline
\end{tabular}

The N-C and C-C bond lengths of the 4,4'-bipy slightly change upon coordination, as do the dihedral angles. In the complex, each $\mathrm{Cu}(\mathrm{II})$ ion is complexed by four ligands in a distorted square planar geometry. The distortion is evidenced by the $\mathrm{N}-\mathrm{Cu}-\mathrm{N}$ and $\mathrm{O}-\mathrm{Cu}-\mathrm{O}$ angles, which are each less than $180^{\circ}$ (see Table 3, Figures 4 and 5).

According to the literature, the interaction of copper(II) acetate with ligands containing nitrogen functional groups results in one of the two following situations: 1) displacement of the water molecules only by the incoming ligand, keeping the dinuclear $\mathrm{Cu}_{2}\left(\mathrm{CH}_{3} \mathrm{COO}\right)_{4}$ unit intact, or 2) coordination of each $\mathrm{Cu}$ (II) ion to two nitrogen-containing ligands and two monodentate acetate groups, adopting a geometry approaching square planar. Examples of both situations have been reported. The former, where the $\mathrm{Cu}_{2}\left(\mathrm{CH}_{3} \mathrm{COO}\right)_{4}$ remains intact,is exemplified by $\left[\mathrm{Cu}_{2}\left(\mathrm{CH}_{3} \mathrm{COO}\right)_{4}(\mathrm{Tz})_{2}\right][9]$ and $\left[\mathrm{Cu}_{2}\left(\mathrm{CH}_{3} \mathrm{COO}\right)_{4}(1,3-\right.$ $\mathrm{Btz})_{2}$ ] [17]. An example of the latter scenario has been reported in the synthesis of $\left[\mathrm{Cu}\left(\mathrm{CH}_{3} \mathrm{COO}\right)_{2}(\mathrm{Im})_{2}\right]$ [7].

Based on the literature and the results reported herein, it seems reasonable to suggest that ligands capable of dissociating the $\mathrm{Cu}_{2}\left(\mathrm{CH}_{3} \mathrm{COO}\right)_{4}$ unit must contain high charge densities on the coordinating nitrogen of the ligand. DFT structural calculations and the calculation of the atomic charges on thiazole, benzothiazole, 4,4`-bipyridine and imidazole were carried out (see Table 4).

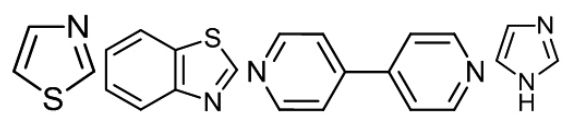

thiazole benzothiazole 4,4'-bipyridine imidazole

Table 4. DFT calculations of the net charge on the coordinating nitrogen atoms on thiazole, benzothiazole, 4,4'-bipyridine, and imidazole ligands.

\begin{tabular}{|c|c|}
\hline Ligand & Net atomic charge \\
\hline thiazole & -0.3624 \\
\hline benzothiazole & -0.4186 \\
\hline 4,4 '-bipyridine & -0.4269 \\
\hline imidazole & -0.4388 \\
\hline
\end{tabular}

From these results it is possible to conclude that the lower charge densities on the coordinating nitrogens in thiazole and benzothiazole are not sufficient to dissociate the $\mathrm{Cu}_{2}\left(\mathrm{CH}_{3} \mathrm{COO}\right)_{4}$ unit when coordinated to copper(II) acetate. 4,4-Bipyridine and imidazole are capable of dissociating the $\mathrm{Cu}_{2}\left(\mathrm{CH}_{3} \mathrm{COO}\right)_{4}$ unit on account of their higher charge densities on nitrogen (Table 4).

Smiesko and Remko[18] carried out a study of the lengths of the $\mathrm{Zn}-\mathrm{N}$ bonds in a series of complexes of zinc and 5-membered heterocyclic ligands. DFT calculations of bond lengths and thermodynamic parameters concluded that particularly short bond lengths were evidenced by the imidazole ligand, due to its unstrained ring geometry and highly delocalized system of $\pi$-electrons that act to extend the lone pair on the coordinating nitrogen radially out from the molecule. These results agree with the idea that higher charge density on the coordinating atom leads to stronger interactions with the $\mathrm{Cu}_{2}\left(\mathrm{CH}_{3} \mathrm{COO}\right)_{4}$, causing a separation of the dinuclear complex.

\section{CONCLUSIONS}

Based on these results, we conclude that the coordination of $4,4^{\prime}$-bipy to $\left[\mathrm{Cu}_{2}\left(\mathrm{CH}_{3} \mathrm{COO}\right)_{4} 2 \mathrm{H}_{2} \mathrm{O}\right]$ produced two notable changes at the $\mathrm{Cu}_{2}\left(\mathrm{CH}_{3} \mathrm{COO}\right)_{4}$ unit. These include the dissociation of the dinuclear unit and the coordination of the bidentate ligand to two $\mathrm{Cu}(\mathrm{II})$ centers, giving a polymeric complex with monodentate acetate ligands. In this complex, the $\mathrm{Cu}(\mathrm{II})$ ions adopt a distorted square planar geometry. It is possible to suggest that the dissociation of the $\mathrm{Cu}_{2}\left(\mathrm{CH}_{3} \mathrm{COO}\right)_{4}$ unit is a result of the high charge density on nitrogen atom of the coordinating ligand.

\section{ACKNOWLEDGMENTS}

The authors thank to Vicerrectoria de Investigación y Desarrollo, Universidad de Concepción (Grant No 211.021.032-1.0)

\section{REFERENCES}

1. H.Uekusa, S. Ohba, Y. Saito, Acta Cryst., C45, 377 (1989).

2. G. Smith, C.H.L. Kennard, K. A. Byriel, Polyhedron, 10, 873 (1991).

3. B. Kozlevcar, I. Leban, I.Turel, P. Segedin, M. Petric, F. Pohleven, A.J.P. White D.J. Williams, J.Sieler, Polyhedron, 18, 755 (1999).

4. M.R. Sundberg, R. Uggla, M. Melník, Polyhedron, 15, 1157 (1996).

5. G.V. Seguel, B.L. Rivas, C. Novas, J. Chil. Chem. Soc., 50, 401 (2005).

6. G.V. Seguel, B.L. Rivas, C. Novas, J. Chil. Chem. Soc.,51, 801 (2006)

7. H. Á. Henriksson, Acta. Cryst.,B33, 1947 (1977).

8. G.V. Seguel, B.L. Rivas, Y. Moreno, O. Peña,Transition Metal Chem., 32, 1106 (2007)

9. G.V. Seguel, B.L. Rivas, J.G. Contreras†, J. Chil. Chem. Soc., 58, 1967 (2013).

10. B.K. Koo, Bull. Korean Chem. Soc., 22, 113 (2001).

11. S. Perlepes, E. Libby, W. E.Streib, K. Folting, G. Christou, Polyhedron, 11, 923 (1992).

12. B.-H. Ye, X.-M. Chen, F. Xue, L.-N. Ji, T. C.W. Mak, Inorg. Chim. Acta, 299, 1 (2000).

13. L.-G. Zhu, S. Kitagawa, H. Miyasaka, H.-C. Chang, Inorg. Chim. Acta, 355, 121 (2003).

14. K. Nakamoto, Infrared and Raman Spectra of Inorganic and Coordination

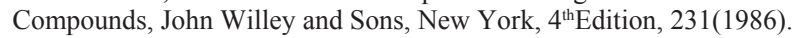

15. B.J. Hathaway, Essays in Chemistry, Academic Press Inc., 2, 71 (1971)

16. P. Jeffrey Hay, J.C. Thibeault, R. Hoffmann, J. Am. Chem. Soc., 97, 4884 (1975).

17. J. Hermle, G. Meyer, Acta Cryst. E67, m1089 (2011).

18. M. Smiesko, M. Remko, Chem. Pap., 59, 310 (2005). 